\title{
The radical departure invitational
}

\author{
Jeffrey Freeman, MD
}

\section{A RANT}

I have taken to climbing into my bed, now renamed the "Life Avoidance Sanctuary and Linear Time Accelerator," and hoping that everything will go away.

I used to be content with mediocrity, accepting that I was doomed to blandness. My kids underachieved, my career was insipid and my hockey skills were insignificant. As an emergency physician, I saw my patients, I thanklessly cured gonorrhea and I pulled lives back from the abyss. I cashed my check without guilt, but was mired in the quicksand of middle age and unfulfilled potential.

Then came a decade of terrorism, genocide, greed and economic stupidity. I don't feel mediocre any more. I am paralyzed, numb and apathetic. I've lost more of my retirement money in the last 6 months than I've earned in the past 5 years. My daughter says fewer words to me in a year than she texts to strangers in a day. I'm fed up with lawyers and lobbyists and hedge fund managers. I'm sick of some medical specialists making more money from procedures they perform in an afternoon than I take home in a month, while I still thanklessly pull lives back from the abyss and do not have a procedure code for disimpaction. Does anyone else share my sense that the next big bubble is the upcoming health care crisis; a crisis fueled by avarice, fear and unrestrained suckling from the public breast with the expectation of infinite capacity despite finite resources and no regulatory decision-making? And when it collapses, might this make credit default swaps look like a sound business decision?

Welcome to "Radical Departure," the back page of CJEM. You are reading a new feature of our illustrious journal; a journal which has a proud history of speaking out when others are mute, and pissing on the Corn Flakes when others won't listen.

We work in emergency departments. We have fed the hungry, comforted the dying, cleaned blood from our shoes. I have cried, apologized, dodged punches and reached satori, though never all on the same shift. I can turn my nose off at will, work 6 consecutive nights over Christmas and hold my urine longer than a camel can hold off drinking. I will not be coddled into keeping my mouth shut because someone doesn't want to hear the truth. Remember "Strive for Excellence"? (Or did you sleep through your high school valedictorian address?)

Have I touched a nerve? Do you have any nerves left that are still capable of screaming out in " 12 out of 10 " pain? Does even the taste of political correctness send you bolting from the room, heaving and grasping for sublingual ondansetron? Are you sick of (choose 1 from List A and 2 from List B):

\section{List A}

- dermatologists

- patients with chronic pain

- academics

- societal parasites

\section{List B}

- raping and pillaging

- whining and mewling

From the Department of Emergency Medicine, University of Michigan, Ann Arbor, Mich.

Submitted Mar. 19, 2009; Accepted Mar. 20, 2009

This article has not been peer reviewed. 


\section{Continued from page 316}

- posturing with self-importance

- getting tax-free incentives

Well you've come to the right place. We need to hear what you have to say. In a society in which being a spectator is a religion, both airport security and politics are mostly theatre and leaving a legacy means high scores on a cell phone game, it's time to clear the inertia from your frontal cortex, speak your mind and make a difference.

Recently, our readership survey confirmed your desire for more editorial commentary, uniquely focused on controversial or Canadian aspects of emergency medicine. We are committed to providing exactly that in this new column - an exploration of ideas and freethinking. We're looking for opinions that are provoca- tive, radical, humorous or simply stimulating. We're in quest of words that need to be spoken, to arouse delight or debate, to chafe the skin or set the nerves afire. And while we reserve the right to peer review and edit, our aim is that no topic is out of bounds, and no opinion will be disregarded.

So throw off your covers and howl at the moon. Send your ideas in condensed form (400 words or less, just to whet our curiosity and interest) to our senior editors at cjem@caep.ca. We'll invite the best and strangest thoughts back for publication on this page.

There now. Doesn't that feel better?

Competing interests: None declared.

Keywords: editorial, controversy, politics

Correspondence to: Dr. Jeffrey Freeman; jfree4@yahoo.com 


\section{Tous comptent \\ sur vous, et \\ vous pouvez \\ compter sur \\ nous pour être..}

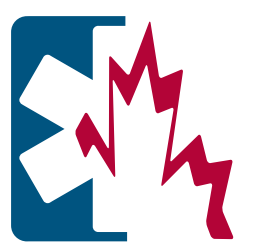

ACMU I Association canadienne des médecins d'urgence

CAEP I Canadian Association of Emergency Physicians

\section{votre réseau votre voix}

votre association

Nous veillons à habiliter les médecins à fournir d'excellents soins d'urgence en leur offrant leadership, formation et représentation.

Découvrez comment vous pouvez compter sur nous. WWW.caep.ca 


\section{Everyone \\ depends on you, \\ you can depend \\ on us to be...}

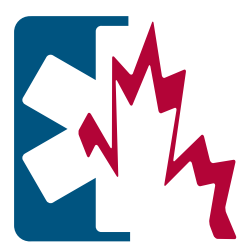

CAEP I Canadian Association of Emergency Physicians

ACMU I Association canadienne des médecins d'urgence

\section{your network your voice your association}

Empowering physicians to provide excellent emergency care through leadership, education and advocacy.

Learn how you can depend on us. WWw.caep.ca 